\title{
Supporting Information \\ En Route to an Efficient Catalytic Asymmetric Synthesis of AS-3201
}

\author{
Tomoyuki Mashiko, Keiichi Hara, Daisuke Tanaka, Yuji Fujiwara, Naoya Kumagai,* and \\ Masakatsu Shibasaki*
}

\section{General}

Infrared (IR) spectra were recorded on a JASCO FT/IR 410 Fourier transform infrared spectrophotometer. NMR spectra were recorded on a JEOL JNM-LA500 spectrometer, operating at $500 \mathrm{MHz}$ for ${ }^{1} \mathrm{H} \mathrm{NMR}, 125.65 \mathrm{MHz}$ for ${ }^{13} \mathrm{C} \mathrm{NMR}$, and $\mathrm{MHz}$ for ${ }^{19} \mathrm{~F} \mathrm{NMR}$. Chemical shifts in $\mathrm{CDCl}_{3}$ were reported downfield from TMS $(=0)$ or in the scale relative to $\mathrm{CHCl}_{3}$ (7.24 ppm) for ${ }^{1} \mathrm{H}$ NMR. For ${ }^{13} \mathrm{C} \mathrm{NMR}$, chemical shifts were reported in the scale relative to $\mathrm{CDCl}_{3}\left(77.0 \mathrm{ppm}\right.$ for $\left.{ }^{13} \mathrm{C} \mathrm{NMR}\right)$ as an internal reference. For ${ }^{19} \mathrm{~F} \mathrm{NMR}$, chemical shifts were reported in the scale relative to $\mathrm{CF}_{3} \mathrm{COOH}(-79.0 \mathrm{ppm})$ as an external reference. FAB mass spectra were measured on JEOL JMS-MS700V. ESI mass spectra were measured on Waters-ZQ4000. Column chromatography was performed with silica gel Merck 60 (230-400 mesh ASTM). Di-tert-butyl azodicarboxylate were purchased from Lancaster Co Ltd and used as received. Catalyst $\mathbf{8}$ was prepared by the known procedure (in ref $10 \mathrm{~g}$ ). 4-Bromo-2-fluorobenzylamine hydrochloride was purchased from Wako Pure Chemical Industries Ltd. Other reagents are purchased and purified through a common procedure.

\section{General Procedure for Catalytic Asymmetric Amination} \section{2-1. General Procedure for Catalytic Asymmetric Amination of Succinimide 4 with} Lanthanum/ligand 7 Complex

To a flame dried test tube was added $\mathrm{La}\left(\mathrm{O}^{i} \mathrm{Pr}\right)_{3}(20 \mu \mathrm{L}, 0.004 \mathrm{mmol}(1 \mathrm{~mol} \%), 0.2 \mathrm{M})$ and $(S)-7$ in THF ( $80 \mu \mathrm{L}, 0.008 \mathrm{mmol}(2 \mathrm{~mol} \%), 0.1 \mathrm{M})$ successively at room temperature under Ar. After stirring the resulting mixture at the same temperature for $1 \mathrm{~h}$ (clear solution turned white suspension gradually), the organic solvent was removed under reduced pressure with Ar atmosphere maintained and resulting residue was dried in vacuo $(1 \mathrm{~h})$. To the test tube was refilled Ar and added ethyl acetate $(0.11 \mathrm{~mL})$ at room temperature. To the resulting suspension was added 4 in ethyl acetate $(0.44 \mathrm{~mL}, 0.4 \mathrm{mmol}, 0.91 \mathrm{M})$ at room temperature and the reaction mixture was cooled to $-40^{\circ} \mathrm{C}$. To the mixture was added tertbutyl azodicarboxylate in ethyl acetate $(0.45 \mathrm{~mL}, 0.48 \mathrm{mmol}, 1.07 \mathrm{M})$ at $-40{ }^{\circ} \mathrm{C}$ and the resulting mixture was stirred at the same temperature. After stirring at the same temperature for $57 \mathrm{~h}, 1 \mathrm{~N} \mathrm{HCl}$ aq. ( $1 \mathrm{~mL}$ ) was added and the resulting mixture was extracted with ethyl acetate three times. The combined organic layers were washed with sat. $\mathrm{NaHCO}_{3}$ and brine, and dried over $\mathrm{Na}_{2} \mathrm{SO}_{4}$. After filtration, organic solvent was evaporated and the yield was determined by the ${ }^{1} \mathrm{H}$ NMR analysis of the resulting residue with $\mathrm{Bn}_{2} \mathrm{O}$ as an internal standard ( $96 \%$ yield, $89 \%$ ee). Enantiomeric excess was determined by chiral HPLC analysis.

Colorless solid; IR (KBr) $v 3292,1735 \mathrm{~cm}^{-1},{ }^{1} \mathrm{H}$ NMR (obscure due to

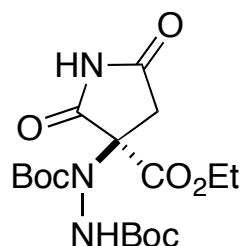


rotamers) $\left(\mathrm{DMSO}-d_{6}\right.$ at $\left.120^{\circ} \mathrm{C}\right) \delta 1.17-1.25(\mathrm{~m}, 3 \mathrm{H}), 1.47(\mathrm{~s}, 18 \mathrm{H}), 3.18(\mathrm{brd}, J=17.1 \mathrm{~Hz}$, $1 \mathrm{H}), 3.42$ (brd, $J=17.7 \mathrm{~Hz}, 1 \mathrm{H}), 4.17-4.24$ (m, 2H), 8.83 (brs, $1 \mathrm{H}), 11.30$ (brs, $1 \mathrm{H}) ;{ }^{13} \mathrm{C}$ NMR NMR (obscure due to rotamers) (DMSO- $d_{6}$ at $120^{\circ} \mathrm{C}$ ) $\delta 13.0,27.2,61.8,72.7,79.2$, 81.6, 152.9, 165.3, 169.0, 174.1; $[\alpha]_{\mathrm{D}}{ }^{28}-55.4\left(c 0.5, \mathrm{CHCl}_{3}\right)(92 \%$ ee); HPLC (DAICEL CHIRALPAK AD-H, methanol/hexane 5/95, flow $1.0 \mathrm{~mL} / \mathrm{min}$, at $40{ }^{\circ} \mathrm{C}$, detection at 210 $\mathrm{nm}$ ) $\mathrm{t}_{\mathrm{R}} 9.5 \mathrm{~min}$ (major) and $12.5 \mathrm{~min}$ (minor); ESI-MS $\mathrm{m} / z 424[\mathrm{M}+\mathrm{Na}]^{+}$; HRMS (FAB ${ }^{+}$) calcd. for $\mathrm{C}_{17} \mathrm{H}_{28} \mathrm{~N}_{3} \mathrm{O}_{8} \mathrm{~m} / z$, $402.1871[\mathrm{M}+\mathrm{H}]^{+}$, found 402.1879 .

\section{2-2. General Procedure for Catalytic Asymmetric Amination of Succinimide 4 with Lanthanum/ligand 7 Complex in the presence of DMA}

To a flame dried test tube was added $\mathrm{La}\left(\mathrm{O}^{i} \mathrm{Pr}\right)_{3}$ in THF $(20 \mu \mathrm{L}, 0.004 \mathrm{mmol}, 0.2 \mathrm{M}),(S)-7$ in THF $(80 \mu \mathrm{L}, 0.008 \mathrm{mmol}, 0.1 \mathrm{M})$ and $N, N$-dimethylacetamide $(7.4 \mathrm{uL}, 0.04 \mathrm{mmol})$ successively at room temperature under Ar. After stirring the resulting mixture at the same temperature for $1 \mathrm{~h}$ (clear solution), the organic solvent was removed under reduced pressure with Ar atmosphere maintained and resulting residue was dried in vacuo (1 h). To the test tube was refilled Ar and added ethyl acetate $(0.11 \mathrm{~mL})$ at room temperature. To the resulting solution was added 4 in ethyl acetate $(0.44 \mathrm{~mL}, 0.4 \mathrm{mmol}, 0.91 \mathrm{M})$ at room temperature and the reaction mixture was cooled to $0{ }^{\circ} \mathrm{C}$. To the mixture was added tertbutyl azodicarboxylate in ethyl acetate $(0.45 \mathrm{~mL}, 0.48 \mathrm{mmol}, 1.07 \mathrm{M})$ at $0{ }^{\circ} \mathrm{C}$ and the resulting mixture was stirred at the same temperature. After stirring for $4 \mathrm{~h}, 1 \mathrm{~N} \mathrm{HCl}$ aq. (1 $\mathrm{mL}$ ) was added and the resulting mixture was extracted with ethyl acetate three times. The combined organic layers were washed with sat. $\mathrm{NaHCO}_{3}$ and brine, and dried over $\mathrm{Na}_{2} \mathrm{SO}_{4}$. After filtration, organic solvent was evaporated and the yield was determined by the ${ }^{1} \mathrm{H}$ NMR analysis of the resulting residue with $\mathrm{Bn}_{2} \mathrm{O}$ as an internal standard $(99 \%$ yield, $89 \%$ ee). Enantiomeric excess was determined by chiral HPLC analysis (HPLC conditions were described in section 2-1).

\section{Synthesis of peptide ligand $(R)-7$.}

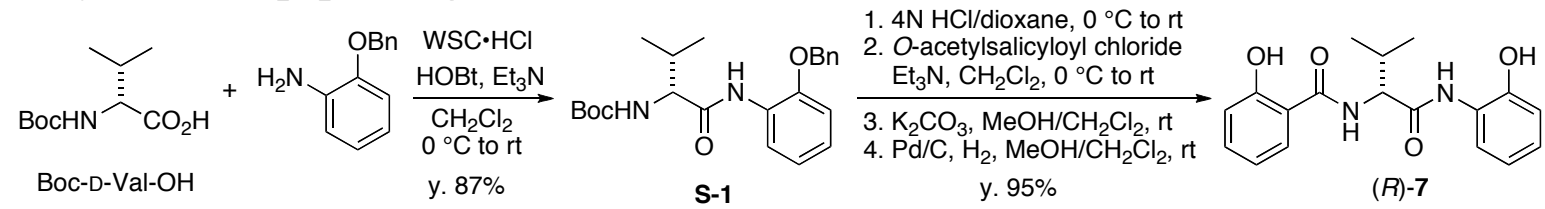

(R)- $\boldsymbol{N}$-(2-Benzyloxyphenyl)-2-(tert-butoxycarbonylamino)-isovaleramide (S-1)

To a stirred suspension of $\mathrm{HOBt} \cdot \mathrm{H}_{2} \mathrm{O}(3.52 \mathrm{~g}, 22.97 \mathrm{mmol}), O$-benzyloxy-2-aminophenol (4.805 g, $24.12 \mathrm{mmol}$ ), Boc-D-Val-OH (4.99 g, $22.97 \mathrm{mmol})$ in $\mathrm{CH}_{2} \mathrm{Cl}_{2}$ (115 mL) were successively added triethylamine $(3.52 \mathrm{~mL}, 25.26 \mathrm{mmol})$ and $\mathrm{EDC} \cdot \mathrm{HCl}(4.84 \mathrm{~g}, 25.26$ mmol) at $0{ }^{\circ} \mathrm{C}$. After stirring at $0{ }^{\circ} \mathrm{C}$ for $1 \mathrm{~h}$ and at room temperature for $12 \mathrm{~h}$, to the resulting mixture was added $1 \mathrm{~N} \mathrm{HCl}$ aq. The mixture was extracted with ether (x3), and the combined organic extracts were washed with sat. $\mathrm{NaHCO}_{3}$ aq. and brine, then dried over $\mathrm{Na}_{2} \mathrm{SO}_{4}$. After filtration and concentration of the organic solvent, the resulting residue was recrystallized from ether/hexane giving the title compound $\mathbf{S - 1}$ as a colorless solid in $87 \%$ 
yield (1st crop. $5.02 \mathrm{~g}, 2$ nd crop $2.92 \mathrm{~g}$ ).

colorless solid; IR (KBr) v 3320, 1692, 1666, 1596, $1522 \mathrm{~cm}^{-1} ;{ }^{1} \mathrm{H}$ $\operatorname{NMR}\left(\mathrm{CDCl}_{3}\right) \delta 0.91(\mathrm{~d}, J=6.7 \mathrm{~Hz}, 3 \mathrm{H}), 0.96(\mathrm{~d}, J=6.7 \mathrm{~Hz}, 3 \mathrm{H})$, 1.40 (s, 9H), 2.14-2.22 (m, 1H), 4.04 (brs, 1H), $5.11(\mathrm{~s}, 2 \mathrm{H}), 6.91-$ $6.97(\mathrm{~m}, 2 \mathrm{H}), 7.01(\mathrm{dd}, J=7.0,7.9 \mathrm{~Hz}, 1 \mathrm{H}), 7.27-7.31(\mathrm{~m}, 1 \mathrm{H})$,

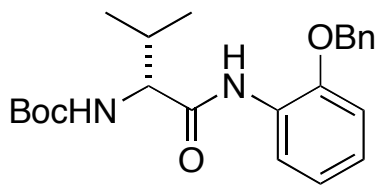
7.32-7.40 (m, 4H), 8.19 (brs, $1 \mathrm{H}), 8.34(\mathrm{brd}, J=7.9 \mathrm{~Hz}, 1 \mathrm{H}) ;{ }^{13} \mathrm{C} \mathrm{NMR}\left(\mathrm{CDCl}_{3}\right) \delta 17.8$, $19.1,28.2,31.1,60.8,70.9,79.9,111.7,120.1,121.4,124.0,127.4,128.3,128.7,136.3$, 147.3, 155.8, 169.6; $[\alpha]_{\mathrm{D}}^{25}+14.8\left(c 0.5, \mathrm{CHCl}_{3}\right)$; ESI-MS $m / z 421[\mathrm{M}+\mathrm{Na}]^{+} ; \mathrm{HRMS}^{2}\left(\mathrm{FAB}^{+}\right)$ calcd. for $\mathrm{C}_{23} \mathrm{H}_{31} \mathrm{~N}_{2} \mathrm{O}_{4} m / z 399.2278[\mathrm{M}+\mathrm{H}]^{+}$, found 399.2285.

\section{(R)- $N$-(2-hydroxyphenyl)-2-salicyloylaminoisovaleramide ((R)-7)}

To a stirred solution of $\mathbf{S - 1}(5.02 \mathrm{~g}, 12.6 \mathrm{mmol})$ in $\mathrm{CH}_{2} \mathrm{Cl}_{2}(20 \mathrm{~mL})$ was added $4 \mathrm{~N}$ $\mathrm{HCl} /$ dioxane $(40 \mathrm{~mL})$ at $0{ }^{\circ} \mathrm{C}$. After stirring at $0{ }^{\circ} \mathrm{C}$ for $10 \mathrm{~min}$ and at room temperature for $1 \mathrm{~h}$, the resulting white suspension was evaporated under reduced pressure. The resulting residue was triturated with ether, and the white solid was collected by filtration then dried under vacuum to give amine hydrochloride as a colorless solid (4.09 $\mathrm{g})$ in $97 \%$ yield. To a stirred suspension of the hydrochloride (4.04 g, $12.1 \mathrm{mmol})$ in $\mathrm{CH}_{2} \mathrm{Cl}_{2}(60 \mathrm{~mL})$, was added triethylamine $(5.04 \mathrm{~mL}, 36.2 \mathrm{mmol})$ and $O$-acetylsalicyloyl chloride $(2.88 \mathrm{~g}, 14.5 \mathrm{mmol})$ at $0{ }^{\circ} \mathrm{C}$. After stirring the resulting solution at $0{ }^{\circ} \mathrm{C}$ for $30 \mathrm{~min}$ and at room temperature for 3.5 $\mathrm{h}$, the reaction mixture was quenched with water. The resulting mixture was extracted with $\mathrm{CH}_{2} \mathrm{Cl}_{2}$ and dried over $\mathrm{Na}_{2} \mathrm{SO}_{4}$. The filtrate was concentrated under reduced pressure and the resulting residue was taken up with $\mathrm{CH}_{2} \mathrm{Cl}_{2}(60 \mathrm{~mL})$ and $\mathrm{MeOH}(60 \mathrm{~mL})$. To the mixture, was added $\mathrm{K}_{2} \mathrm{CO}_{3}(3.34 \mathrm{~g}, 24.1 \mathrm{mmol})$ and the resulting suspension was stirred at room temperature for $30 \mathrm{~min}$. The reaction was quenched with sat. $\mathrm{NH}_{4} \mathrm{Cl}$ aq., $\mathrm{MeOH}$ was removed under reduced pressure, and the resulting mixture was extracted with ethyl acetate. The combined organic solvent was washed with sat. $\mathrm{NaHCO}_{3}$ aq. and brine, the dried over $\mathrm{Na}_{2} \mathrm{SO}_{4}$. Evaporation of the organic solvent gave the residue containing Bn-protected $(R)-7$. To a stirred solution of the residue in $\mathrm{CH}_{2} \mathrm{Cl}_{2}(40 \mathrm{~mL})$ and $\mathrm{MeOH}(40 \mathrm{~mL})$, was added $\mathrm{Pd} / \mathrm{C}$ (505 mg, 10\% w/w, Merck) and the resulting suspension was stirred under $\mathrm{H}_{2}$ atmosphere (1 atm) at room temperature. After $1 \mathrm{~h}$ of stirring, the reaction mixture was filtered through a pad of Celite with $\mathrm{MeOH}$, and the filtrate was concentrated under reduced pressure. The resulting residue was recrystallized form $\mathrm{CH}_{2} \mathrm{Cl}_{2} /$ hexane to give $(R)-7$ as a colorless solid $(3.89 \mathrm{~g}, 98 \%)$. Optical purity of the product was confirmed as $>99 \%$ ee by chiral HPLC analysis.

colorless solid; IR (KBr) v 3291, 2965, 1637, 1542, $1497 \mathrm{~cm}^{-}$

${ }^{1} ;{ }^{1} \mathrm{H} \mathrm{NMR}\left(\mathrm{CDCl}_{3}\right) \delta 1.07(\mathrm{dd}, J=1.2,6.8 \mathrm{~Hz}, 6 \mathrm{H}), 2.25-$

$2.35(\mathrm{~m}, 1 \mathrm{H}), 4.60(\mathrm{dd}, J=7.6,8.0 \mathrm{~Hz}, 1 \mathrm{H}), 6.71(\mathrm{dd}, J=$

$7.3,8.0 \mathrm{~Hz}, 1 \mathrm{H}), 6.75(\mathrm{dd}, J=6.7,7.3 \mathrm{~Hz}, 1 \mathrm{H}), 6.87(\mathrm{~d}, J=$

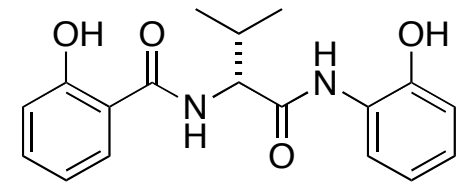

$8.3 \mathrm{~Hz}, 1 \mathrm{H}), 6.98(\mathrm{dd}, J=7.2,8.1 \mathrm{~Hz}, 1 \mathrm{H}), 7.26(\mathrm{dd}, J=7.3,8.3 \mathrm{~Hz}, 1 \mathrm{H}), 7.45$ (dd, $J=7.6$, $8.3 \mathrm{~Hz}, 1 \mathrm{H}), 7.54-7.56$ (m, 1H), 7.95 (brs, 1H), 8.63 (brs, $1 \mathrm{H}), 8.92$ (brd, $J=18.6 \mathrm{~Hz}, 1 \mathrm{H}$ ), $11.5(\mathrm{~s}, 1 \mathrm{H}) ;{ }^{13} \mathrm{C}$ NMR $\delta 18.9,19.5,31.3,60.3,114.8,118.0,118.1,119.6,120.7,122.3$, $125.1,126.9,127.6,134.7,147.8,159.9,169.7,171.4 ;[\alpha]_{\mathrm{D}}{ }^{27}+74.1\left(c 0.5, \mathrm{CHCl}_{3}\right)$; ESI-MS $m / z 351[\mathrm{M}+\mathrm{Na}]^{+}$; HRMS $\left(\mathrm{FAB}^{+}\right)$calcd. for $\mathrm{C}_{18} \mathrm{H}_{20} \mathrm{~N}_{2} \mathrm{O}_{4} \mathrm{Cs}, m / z 461.04721[\mathrm{M}+\mathrm{Cs}]^{+}$, found 
461.0468. HPLC (DAICEL CHIRALPAK AS-H, 2-propanol/hexane 1/9, flow $1.0 \mathrm{~mL} / \mathrm{min}$, at $40{ }^{\circ} \mathrm{C}$, detection at $254 \mathrm{~nm}$ ) $\mathrm{t}_{\mathrm{R}} 25.2 \mathrm{~min}$ (major) and $27.0 \mathrm{~min}$ (minor).

\section{Synthesis of AS-3201 ((-)-1: ranirestat)}

$\boldsymbol{R}$-(-)-3-Ethoxycarbonyl-3-( $N, N^{\prime}$-di(tert-butoxycarbonyl)hydrozino)pyrrolidin-2,5dione hydrochloride ((-)-6)

To a flame dried $300 \mathrm{~mL}$ round-bottomed flask was added $\mathrm{La}\left(\mathrm{O}^{i} \mathrm{Pr}\right)_{3}(5.85 \mathrm{~mL}, 1.17 \mathrm{mmol}$, $0.2 \mathrm{M}), N, N$-dimethylacetamide $(1.09 \mathrm{~mL}, 11.7 \mathrm{mmol})$ and $(R)-7 \mathrm{in}$ THF $(23.3 \mathrm{~mL}, 2.33$ mmol, $0.1 \mathrm{M})$ successively at room temperature under Ar. After stirring the resulting mixture at the same temperature for $1 \mathrm{~h}$ (clear solution), the organic solvent was removed under reduced pressure with Ar atmosphere maintained and resulting residue was dried in vacuo $(1 \mathrm{~h})$. To the flask was added chloroform $(16.8 \mathrm{~mL})$ at room temperature under air. To the resulting suspension was added 4 in chloroform $(50 \mathrm{~mL}, 58.4 \mathrm{mmol}, 1.2 \mathrm{M})$ at room temperature and the reaction mixture was cooled to $0{ }^{\circ} \mathrm{C}$. To the mixture was added tertbutyl azodicarboxylate in chloroform $(50 \mathrm{~mL}, 70.1 \mathrm{mmol}, 1.4 \mathrm{M})$ at $0{ }^{\circ} \mathrm{C}$ and the resulting mixture was stirred under air in the flask fitted with $\mathrm{CaCl}_{2}$ tube. After stirring at the same temperature for $90 \mathrm{~min}, 1 \mathrm{~N} \mathrm{HCl}$ aq. $(100 \mathrm{~mL})$ was added and the resulting mixture was extracted with ethyl acetate three times. The combined organic layers were washed with sat. $\mathrm{NaHCO}_{3}$ and brine, and dried over $\mathrm{Na}_{2} \mathrm{SO}_{4}$. The residue obtained upon concentration was purified by silica gel column chromatography $\left(\mathrm{CH}_{2} \mathrm{Cl}_{2} /\right.$ cyclohexane/ethyl acetate 4/4/1) to give (-)-6 as a colorless solid (23.4 g, >99\% yield, 92\% ee). HPLC conditions were the same as described in section 2-1.

\section{$\boldsymbol{R}$-(-)-3-Ethoxycarbonyl-3-hydrozinopyrrolidin-2,5-dione hydrochloride}

To a stirred solution of $6(22.0 \mathrm{~g}, 54.8 \mathrm{mmol})$ in toluene $(550 \mathrm{~mL})$ was passed $\mathrm{HCl}$ gas at 0 ${ }^{\circ} \mathrm{C}$ for $2.5 \mathrm{~h}$. Toluene was removed under reduced pressure to give title compound $(13.0 \mathrm{~g}$, $99 \%$ yield) as a colorless solid.

colorless solid; IR $(\mathrm{KBr}) v 3232,3152,1744,1713,1578 \mathrm{~cm}^{-1} ;{ }^{1} \mathrm{H}$ NMR $\left(\mathrm{MeOH}-d_{4}\right) \delta 1.30(\mathrm{t}, J=7.2 \mathrm{~Hz}, 3 \mathrm{H}), 2.83(\mathrm{~d}, J=18.0 \mathrm{~Hz}, 1 \mathrm{H}), 3.20(\mathrm{~d}$, $J=18.0 \mathrm{~Hz}, 1 \mathrm{H}), 4.31-4.37(\mathrm{~m}, 2 \mathrm{H}) ;{ }^{13} \mathrm{C} \mathrm{NMR} \delta 14.2,40.9,64.7,68.4$, 169.4, 174.7, 175.5; $[\alpha]_{\mathrm{D}}{ }^{25}-20.5$ (c 1.0, MeOH); ESI-MS $m / z 202$ $[\mathrm{M}-\mathrm{Cl}]^{+}$; HRMS $\left(\mathrm{FAB}^{+}\right)$calcd. for $\mathrm{C}_{7} \mathrm{H}_{13} \mathrm{~N}_{3} \mathrm{O}_{4}, \mathrm{~m} / z 202.0822[\mathrm{M}-\mathrm{Cl}]^{+}$, found 202.0829 .

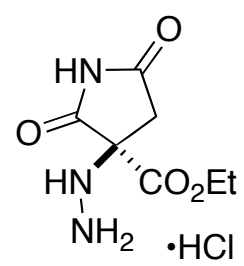

\section{$\boldsymbol{R}$-(-)-3-Amino-3-ethoxycarbonylpyrrolidin-2,5-dione (3)}

To a stirred solution of (-)-6 (11.9 g, $50.0 \mathrm{mmol})$ in ethanol $(99.5 \%, 650 \mathrm{~mL})$ was added Raney Nickel (11.9 g, washed with $99.5 \% \mathrm{EtOH}$ x 20) and the resulting mixture was stirred for $42 \mathrm{~h}$ at room temperature. The reaction mixture was filtered through a pad of Celite (washed with $\mathrm{MeOH}$ ) and the filtrate was concentrated to give $R$-(-)-3-amino-3ethoxycarbonylpyrrolidin-2,5-dione as a colorless solid. Recrystallization from 2-propanol afforded $3(6.1 \mathrm{~g}, 66 \%)$ in $>99 \%$ ee. Ee was determined after converting into $\mathrm{N}-\mathrm{Cbz}$ protected compound, which was analyzed by chiral HPLC analysis (HPLC conditions were described in ref $8 \mathrm{a})$. 
colorless solid; IR $(\mathrm{KBr}) v 3232,3152,1744,1713,1578 \mathrm{~cm}^{-1} ;{ }^{1} \mathrm{H}$ NMR $\left(\mathrm{MeOH}, \mathrm{d}_{4}\right) \delta 1.26(\mathrm{t}, J=7.0 \mathrm{~Hz}, 3 \mathrm{H}), 2.66(\mathrm{~d}, J=18.0 \mathrm{~Hz}, 1 \mathrm{H}), 3.30(\mathrm{~d}, J=$ $18.0 \mathrm{~Hz}, 1 \mathrm{H}), 4.22(\mathrm{q}, J=7.0 \mathrm{~Hz}, 2 \mathrm{H}) ;{ }^{13} \mathrm{C}$ NMR $\delta 14.2,43.4,63.8,65.4$, 171.5, 177.3, 178.7; $[\alpha]_{\mathrm{D}}{ }^{27}-31.0$ (c 1.5); ESI-MS $m / z, 187[\mathrm{M}+\mathrm{H}]^{+}$; HRMS $\left(\mathrm{FAB}^{+}\right)$calcd. for $\mathrm{C}_{7} \mathrm{H}_{11} \mathrm{~N}_{2} \mathrm{O}_{4} \mathrm{~m} / z$ 187.0713 $[\mathrm{M}+\mathrm{H}]^{+}$, found 187.0715. HPLC

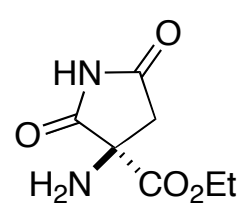
(DAICEL CHIRALPAK AS-H, ethanol/hexane $1 / 9$, flow $2.0 \mathrm{~mL} / \mathrm{min}$, at $40{ }^{\circ} \mathrm{C}$, detection at $254 \mathrm{~nm}) \mathrm{t}_{\mathrm{R}} 11.0 \mathrm{~min}$ (major) and $16.8 \mathrm{~min}$ (minor).

\section{$\boldsymbol{R}$-(-)-3-Ethoxycarbonyl-3-(pyrrol-1-yl)pyrrolidin-2,5-dione (8)}

To the THF $(260 \mathrm{~mL})$ solution of $3(5.92 \mathrm{~g}, 31.8 \mathrm{mmol})$ was added 2,5-dihydroxyfuran (55.0 $\mathrm{mL}, 47.7 \mathrm{mmol}, 0.87 \mathrm{M} / \mathrm{H}_{2} \mathrm{O}$ ) (prepared by refluxing the mixture of 2,5dimethoxyfuran and $\mathrm{H}_{2} \mathrm{O}$ ) at room temperature. The resulting yellow solution was stirred at $40{ }^{\circ} \mathrm{C}$ for $12 \mathrm{~h}$ in the dark. The reaction mixture was extracted with ethyl acetate $\mathrm{x} 3$ and the combined organic layers were washed with brine and dried over $\mathrm{Na}_{2} \mathrm{SO}_{4}$. Filtration and concentration gave yellow residue, which was purified by silica gel column chromatography (hexane/ethyl acetate $4 / 1)$ to give $\mathbf{8}$ as a pale yellow oil $(6.41 \mathrm{~g}, 85 \%$ yield). This is a known compound, Reg \# 159213-79-1.

\section{$\boldsymbol{R}$-(-)-3-Ethoxycarbonyl-3-(2-(trichloroacetyl)pyrrol-1-yl)pyrrolidin-2,5-dione (9)}

Trichloroacetyl chloride $(11.7 \mathrm{~mL}, 105.2 \mathrm{mmol})$ was added to $8(6.21 \mathrm{~g}, 26.3 \mathrm{mmol})$ and the resulting mixture was stirred at $80{ }^{\circ} \mathrm{C}$ for $10 \mathrm{~h}$. The reaction mixture was cooled to room temperature and diluted with ethyl acetate $(80 \mathrm{~mL})$. The resulting mixture was cooled to $0{ }^{\circ} \mathrm{C}$ and sat. $\mathrm{NaHCO}_{3}$ was added to neutralize and stirred at the same temperature for 0.5 $\mathrm{h}$. The mixture was extracted with ethyl acetate $\mathrm{x} 3$ and combined organic layers were washed with brine and dried over $\mathrm{Na}_{2} \mathrm{SO}_{4}$. The organic solvent was removed under reduced pressure to give yellow residue, which was purified by silica gel column chromatography to give 9 as a colorless solid (9.03 g, 90\% yield). This is a known compound, Reg \# 15921326-0.

\section{$R$-(-)-2-(4-Bromo-2-fluorobenzyl)-1,2,3,4-tetrahydro[1,2-a]pyrrolopyradine-4-spiro- 3'-pyrrolidine-1,2',3,5'-tetrone ((-)-1: AS-3201, ranirestat)}

To a stirred solution of $(8.27 \mathrm{~g}, 21.7 \mathrm{mmol})$ in dry DMF $(21.7 \mathrm{~mL})$ was added 4-bromo-2fluorobenzylamine (prepared from partition with aq. sodium carbonate) (5.309 g, 26.0 mmol) successively at room temperature. After stirring at the same temperature for $5 \mathrm{~h}, 1 \mathrm{~N}$ $\mathrm{HCl}$ aq. was added and the resulting mixture was extracted with ether/ethyl acetate $=1 / 1$ three times. The combined organic layers were washed with brine and dried over $\mathrm{Na}_{2} \mathrm{SO}_{4}$. The residue obtained upon concentration was purified by silica gel column chromatography (hexane/ethyl acetate $4 / 1$ to $1 / 1)$ to give (-)-1 as a colorless solid (6.46 g, 71\% yield).

colorless solid; $v$ IR $(\mathrm{KBr}) v 3217,3111,1732,1676,1548 \mathrm{~cm}^{-1}$; ${ }^{1} \mathrm{H}$ NMR $\left(\mathrm{DMSO}-d_{6}\right) \delta 3.51$ (brs, $\left.2 \mathrm{H}\right), 4.91(\mathrm{~d}, J=16.1 \mathrm{~Hz}, 1 \mathrm{H})$, $4.99(\mathrm{~d}, J=16.1 \mathrm{~Hz}, 1 \mathrm{H}), 6.47(\mathrm{dd}, J=2.9,4.0 \mathrm{~Hz}, 1 \mathrm{H}), 7.06-$ $7.11(\mathrm{~m}, 2 \mathrm{H}), 7.28-7.31(\mathrm{~m}, 1 \mathrm{H}), 7.45-7.49(\mathrm{~m}, 1 \mathrm{H}), 7.68(\mathrm{~s}, 1 \mathrm{H})$, 12.13 (brs, $1 \mathrm{H}$ ); ${ }^{13} \mathrm{C}$ NMR (DMSO- $\left.d_{6}\right) \delta 36.4,42.8,68.8,112.7$,

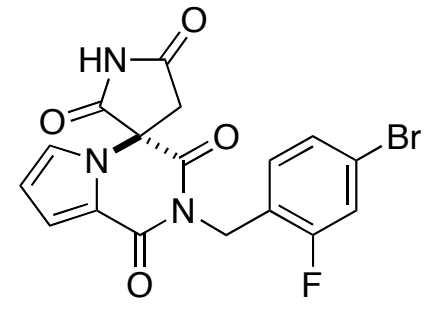


$116.0,118.7\left(J_{\text {C-F }}=25.0 \mathrm{~Hz}\right), 120.6\left(J_{\mathrm{C}-\mathrm{F}}=9.5 \mathrm{~Hz}\right), 121.5,122.9\left(J_{\mathrm{C}-\mathrm{F}}=15.6 \mathrm{~Hz}\right), 125.2$, $127.5,130.4,155.6,159.7\left(J_{\mathrm{C}-\mathrm{F}}=251.5 \mathrm{~Hz}\right), 166.9,172.2,174.3 ;{ }^{19} \mathrm{~F} \mathrm{NMR}\left(\mathrm{CDCl}_{3}\right) \delta$ $-115.1(\mathrm{dd}, J=8.5,8.9 \mathrm{~Hz}) ;[\alpha]_{\mathrm{D}}{ }^{27}-5.2(c 0.8)$; ESI-MS $m / z 442[\mathrm{M}+\mathrm{Na}]^{+}$; HRMS $\left(\mathrm{FAB}^{+}\right)$ calcd. for $\mathrm{C}_{17} \mathrm{H}_{12} \mathrm{~N}_{3} \mathrm{O}_{4} \mathrm{FBr} m / z 419.9990[\mathrm{M}+\mathrm{H}]^{+}$, found 419.9986 .

\section{ESI-QFT MS analysis of $\mathbf{L a} /(\mathbf{S})-7$ complex.}

Preparation of La/(S)-7 complex for MS analysis.

To a flame dried test-tube $(20 \mathrm{~mL})$ were added ligand $(S)-7$ in THF $(200 \mu \mathrm{L}, 0.02 \mathrm{mmol}$, $0.1 \mathrm{M})$ and $\mathrm{La}\left(\mathrm{O}^{i} \mathrm{Pr}\right)_{3}(50 \mu \mathrm{L}, 0.01 \mathrm{mmol}, 0.2 \mathrm{M})$ successively at room temperature under Ar atmosphere and the resulting mixture was stirred at the same temperature for $1 \mathrm{~h}$. The resulting suspension was evaporated under reduced pressure. The white residue was dried in vacuo at room temperature for $1 \mathrm{~h}$. The residue was dissolved in dry acetonitrile just before injection.

ESI-QFT MS spectra of $\mathrm{La} /(S)$-7 were recorded on QFT Hybrid Mass Spectrometer (at JASCO International Co., Ltd.) (Chart S1). In the positive-ion mode experiment, Chart S1 illustrated two prominent peaks $\mathrm{m} / \mathrm{z}=938.0625,1093.6297$, which corresponds to the complex composed of $\left[\mathrm{La}_{4}(\mathrm{O}) /(\text { ligand } 7)_{4}\right]^{2+},\left[\mathrm{La}_{4} /(\text { ligand } 7)_{5}\right]^{2+}$, respectively. Observed isotopic distribution pattern of each complex matches theoretical pattern (Chart S2, S3).

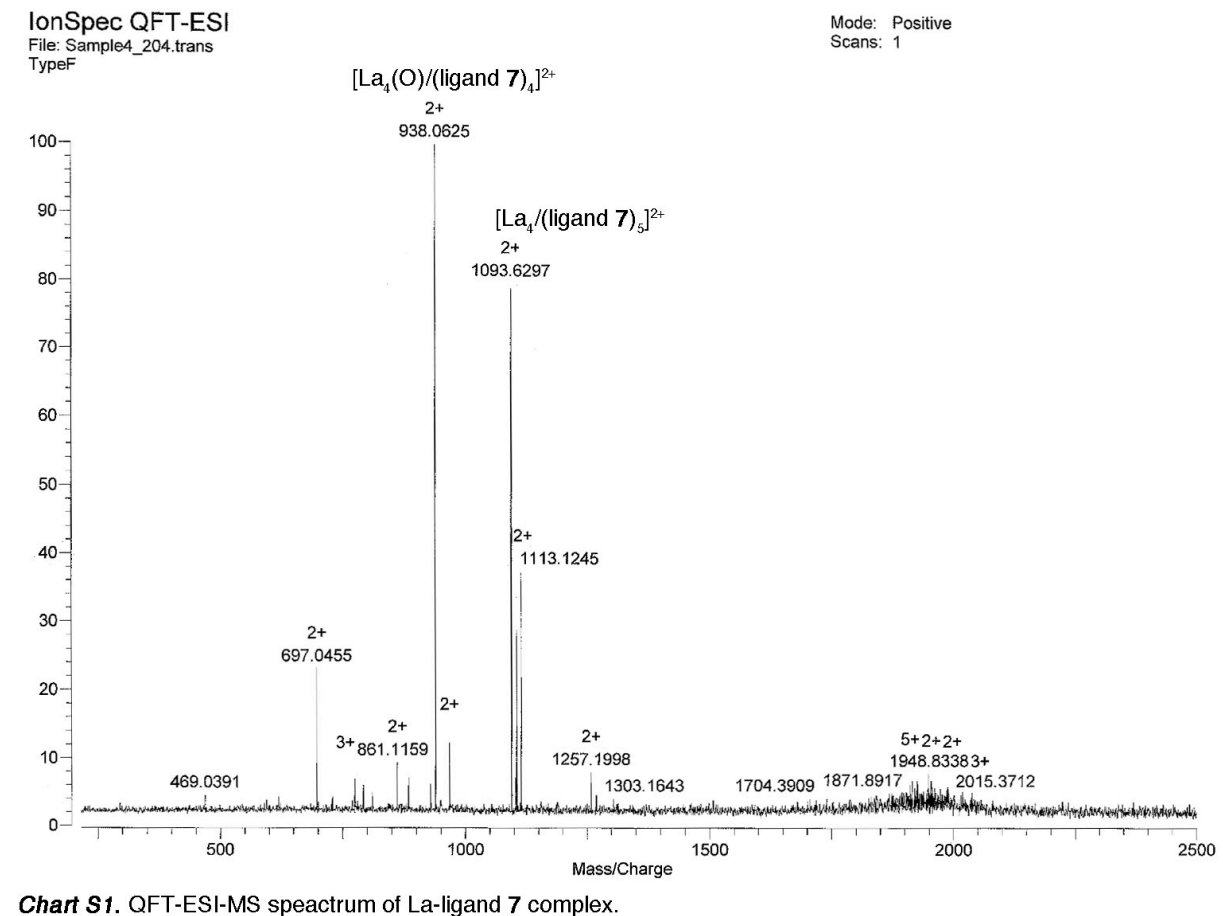

Chart S1. QFT-ESI-MS speactrum of La-ligand 7 complex. 

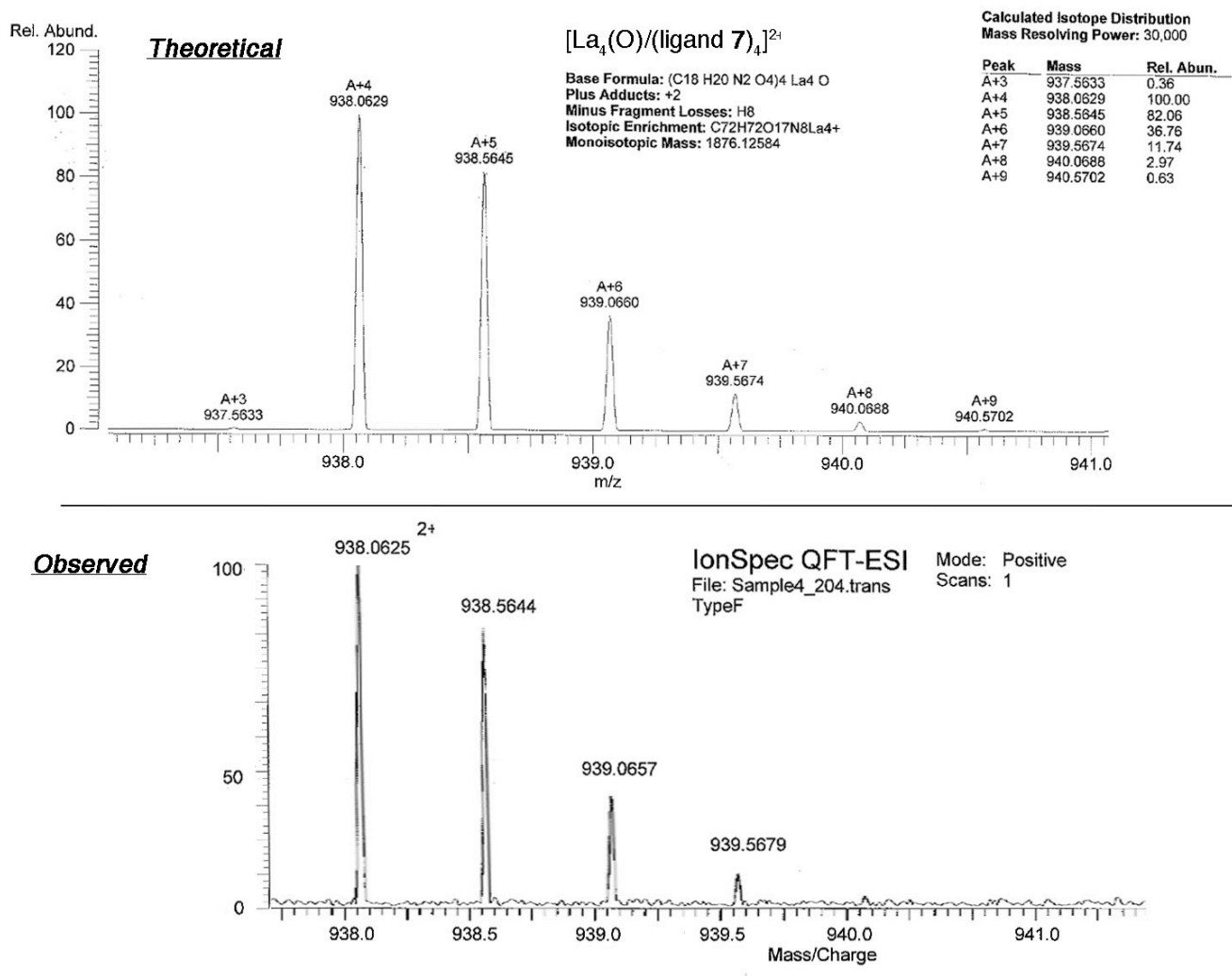

Chart S2. Isotopic distribution pattern of $\left[\mathrm{La}_{4}(\mathrm{O}) /(\text { ligand } 7)_{4}\right]^{2+}$. 


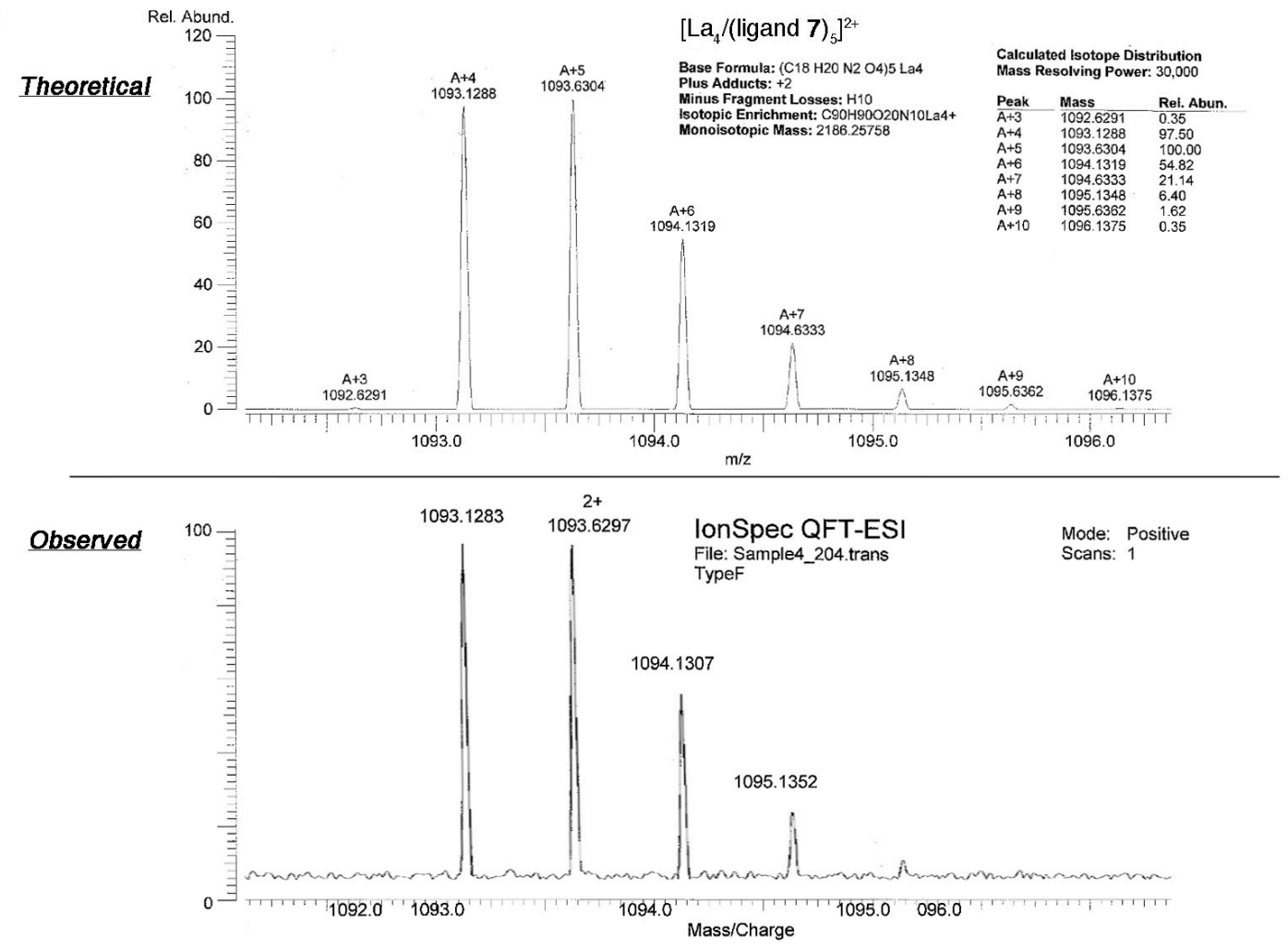

Chart S3. Isotopic distribution pattern of $\left[\mathrm{La}_{4}(\mathrm{O}) /(\text { ligand } 7)_{5}\right]^{2+}$.

\section{NMR Spectra.}




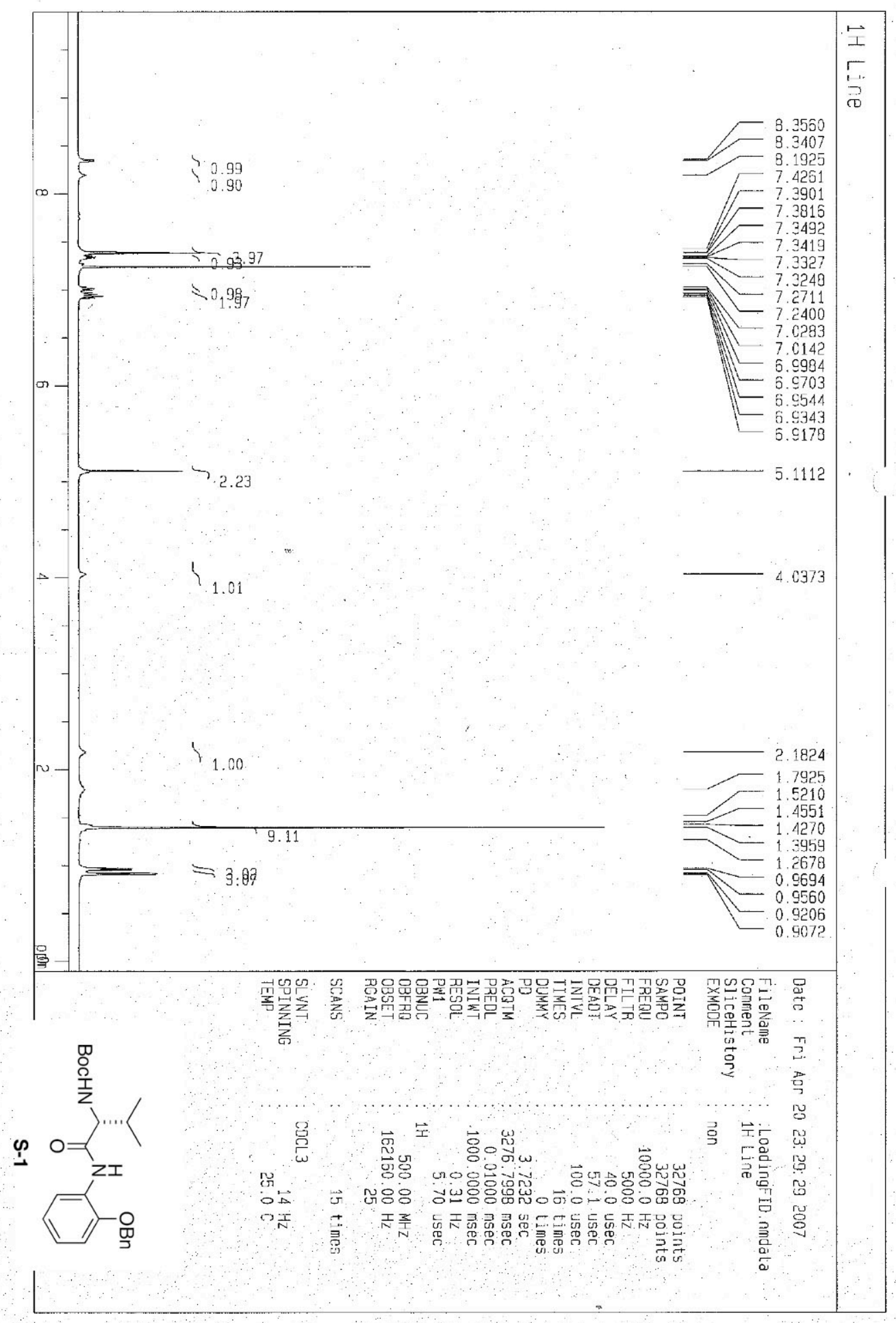




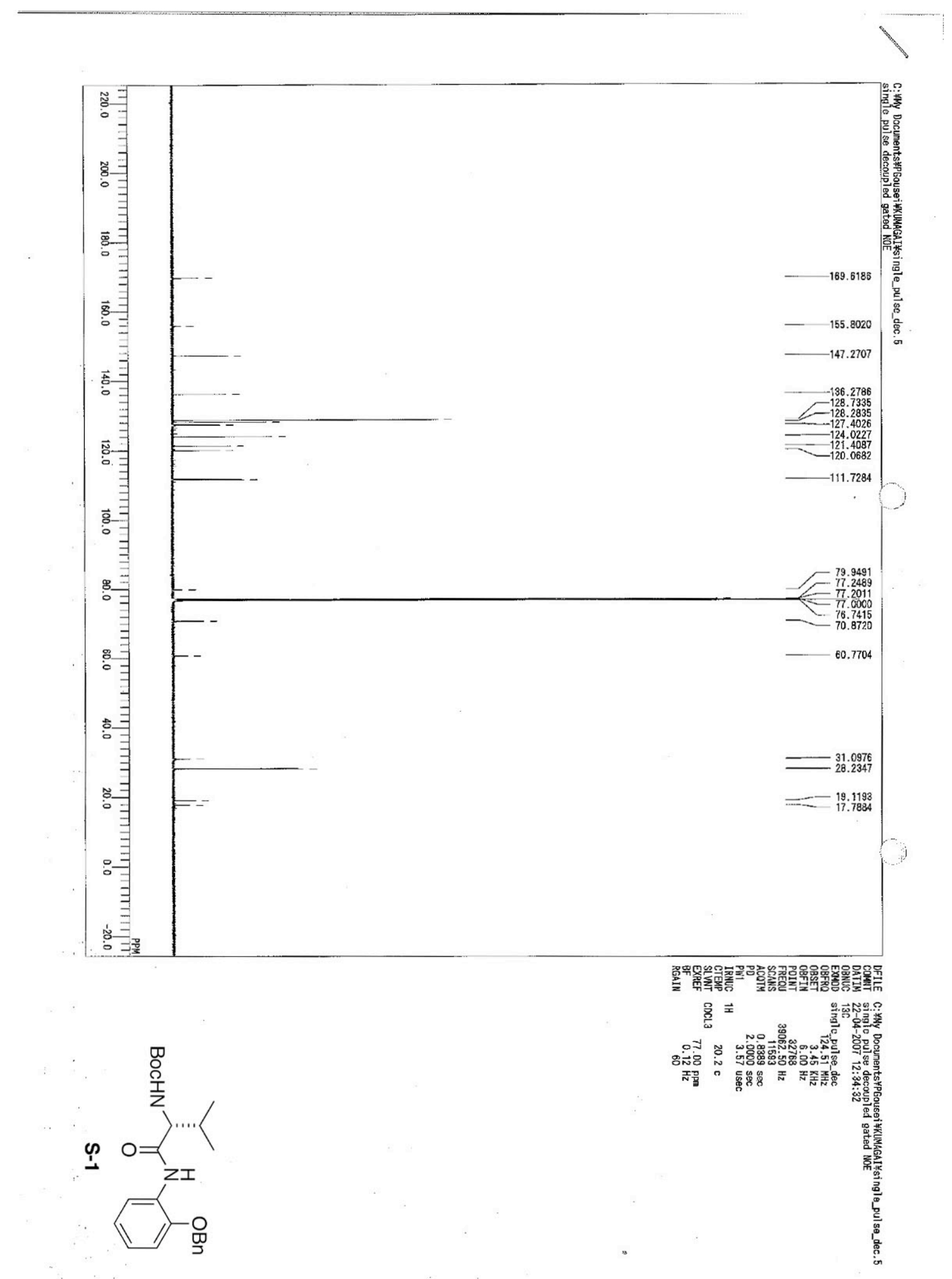




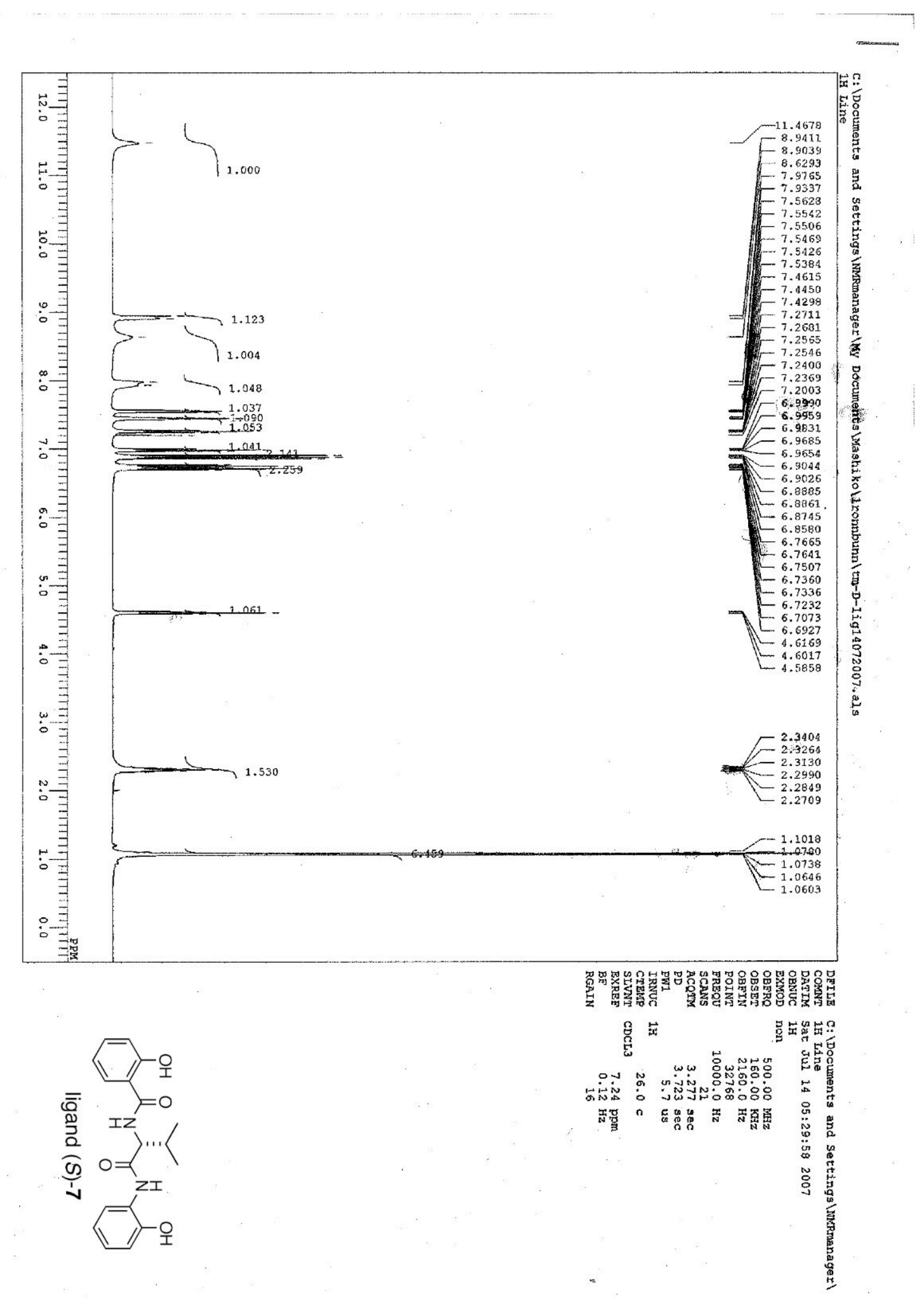




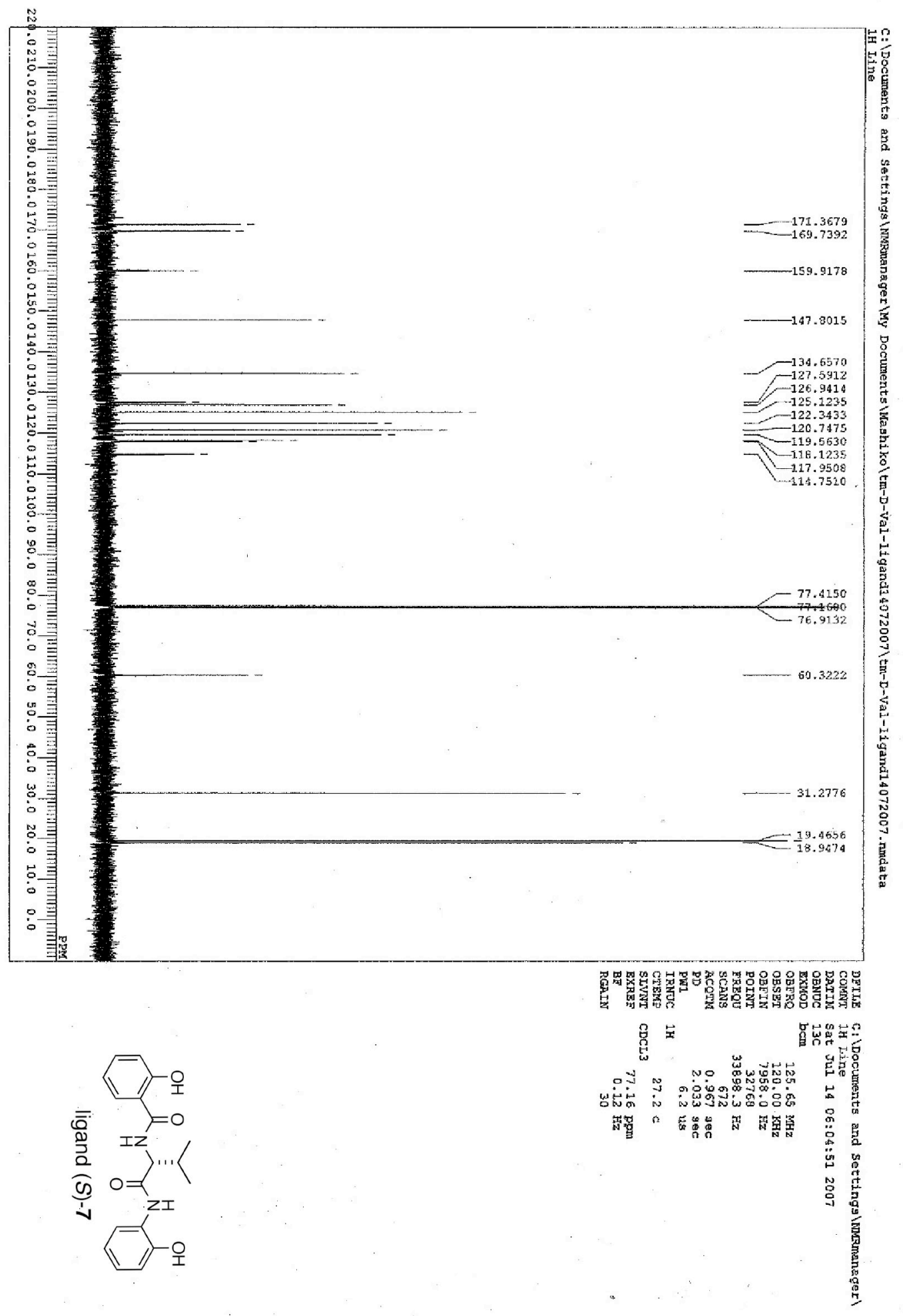




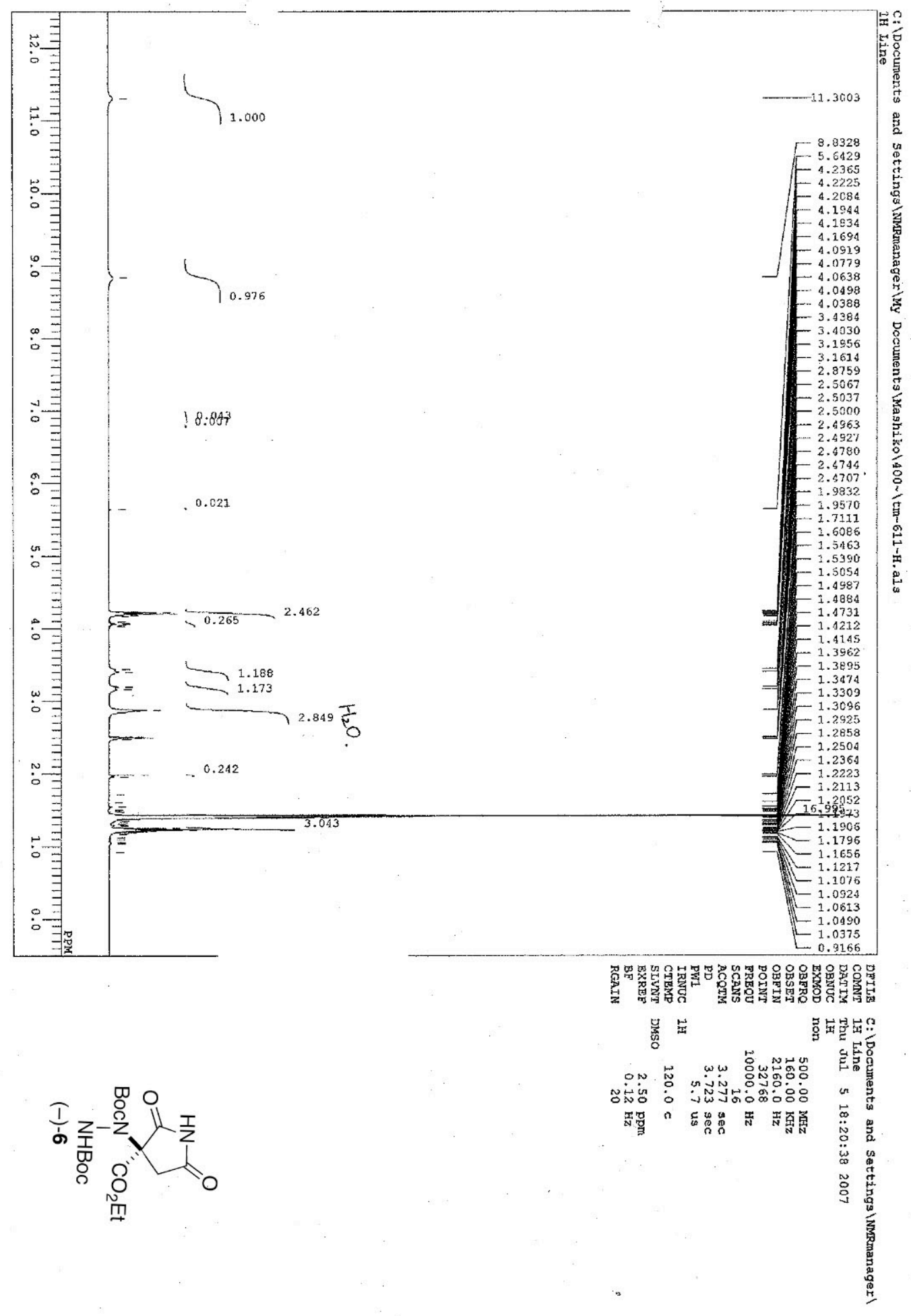




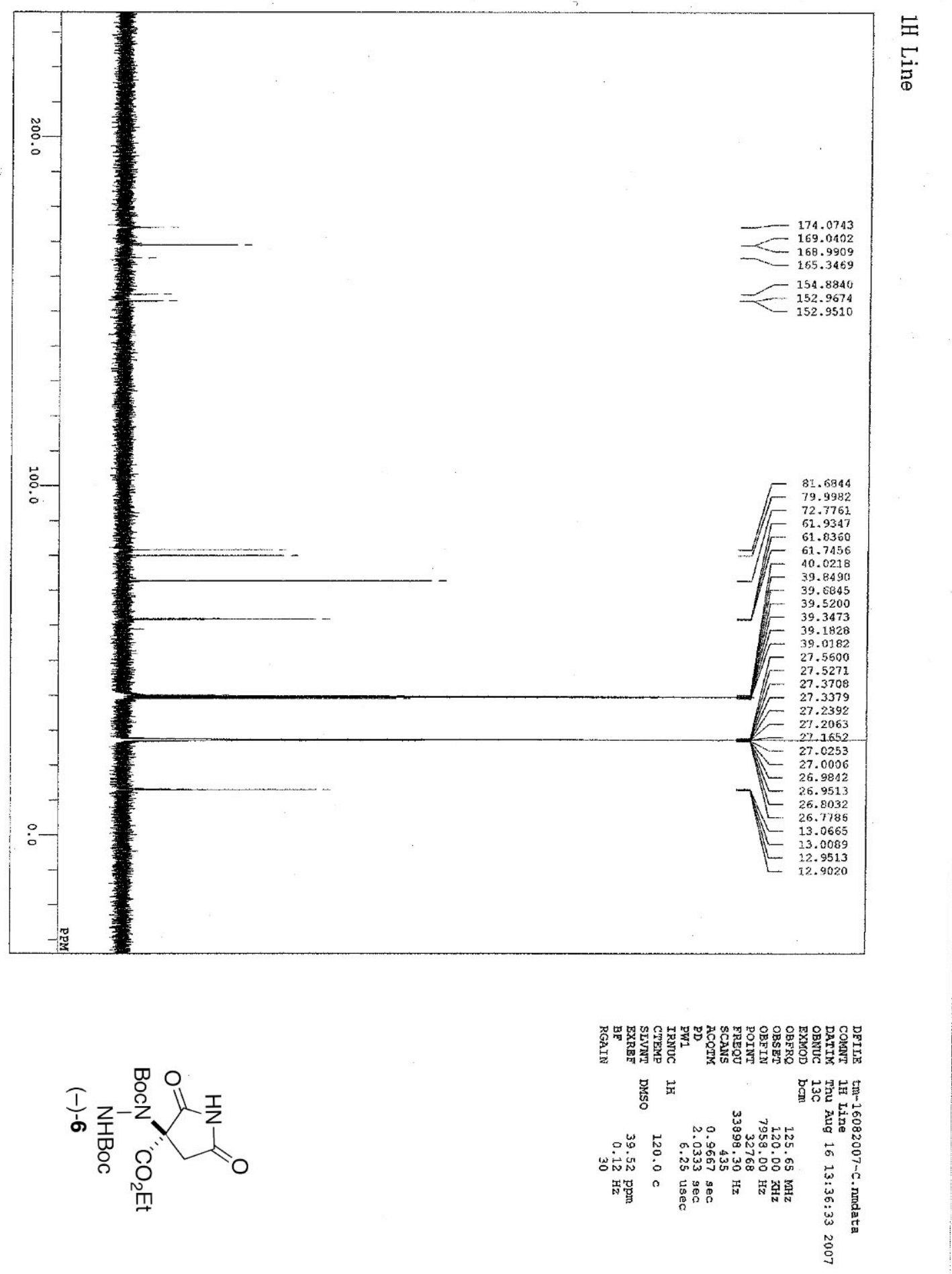




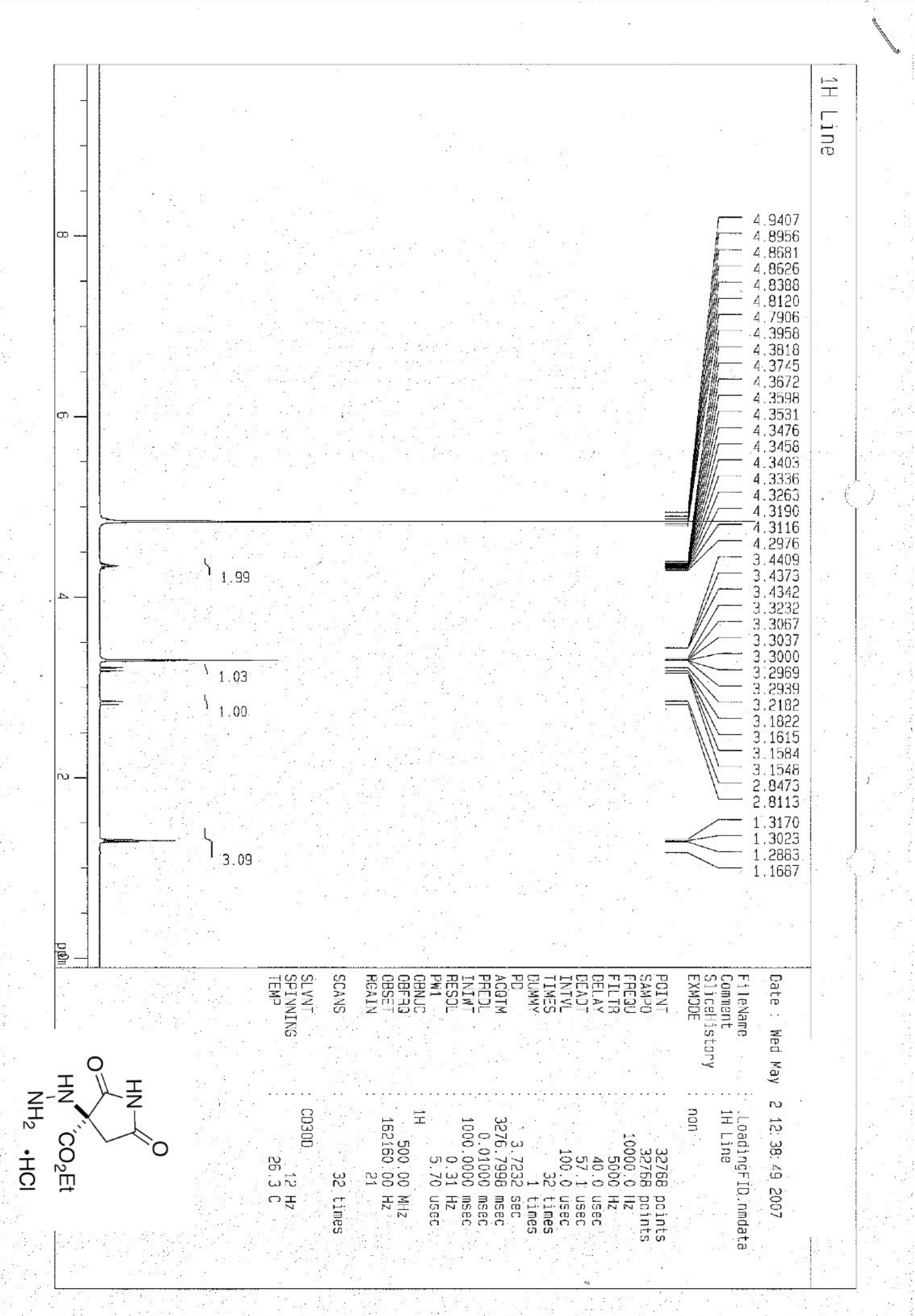




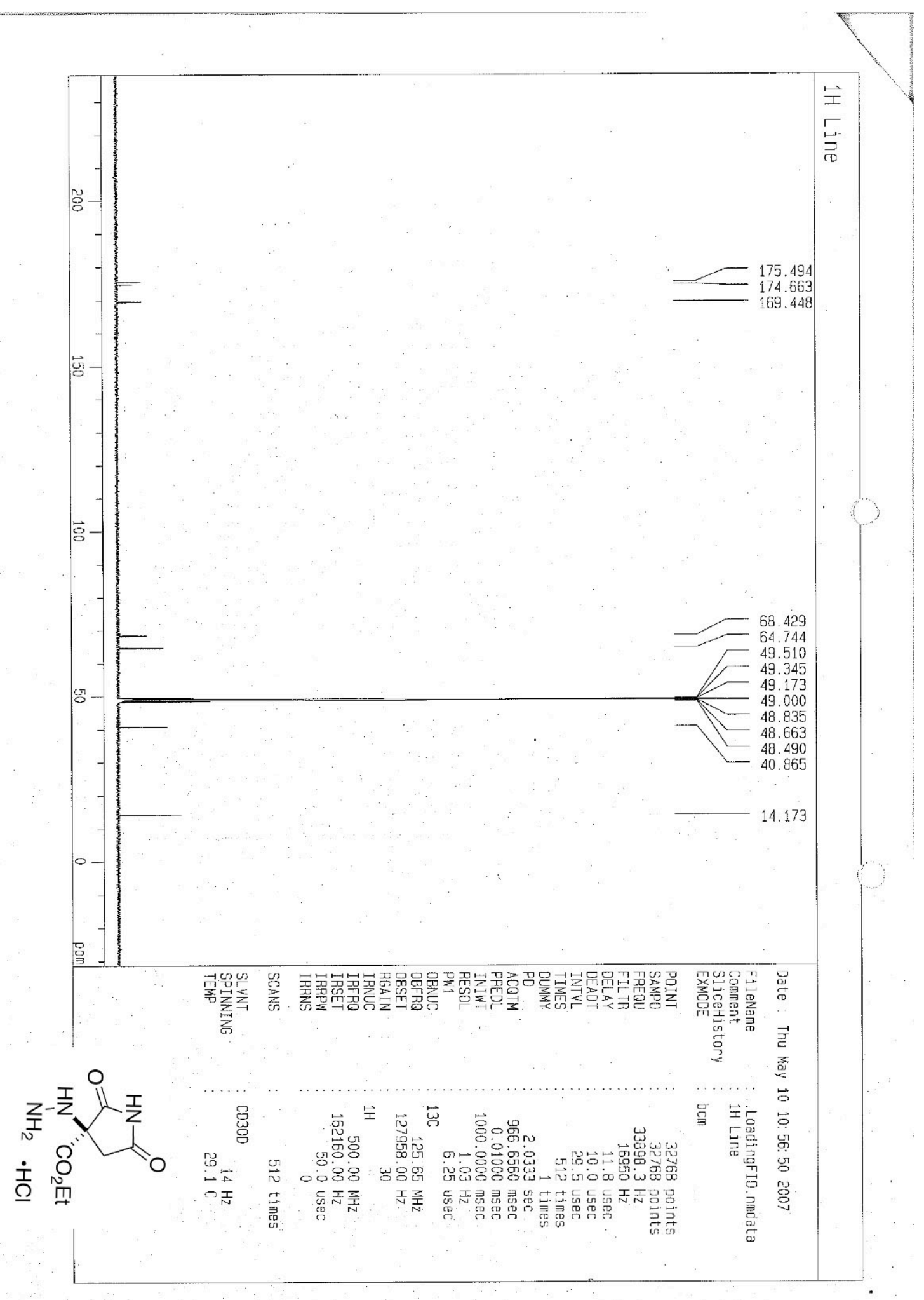




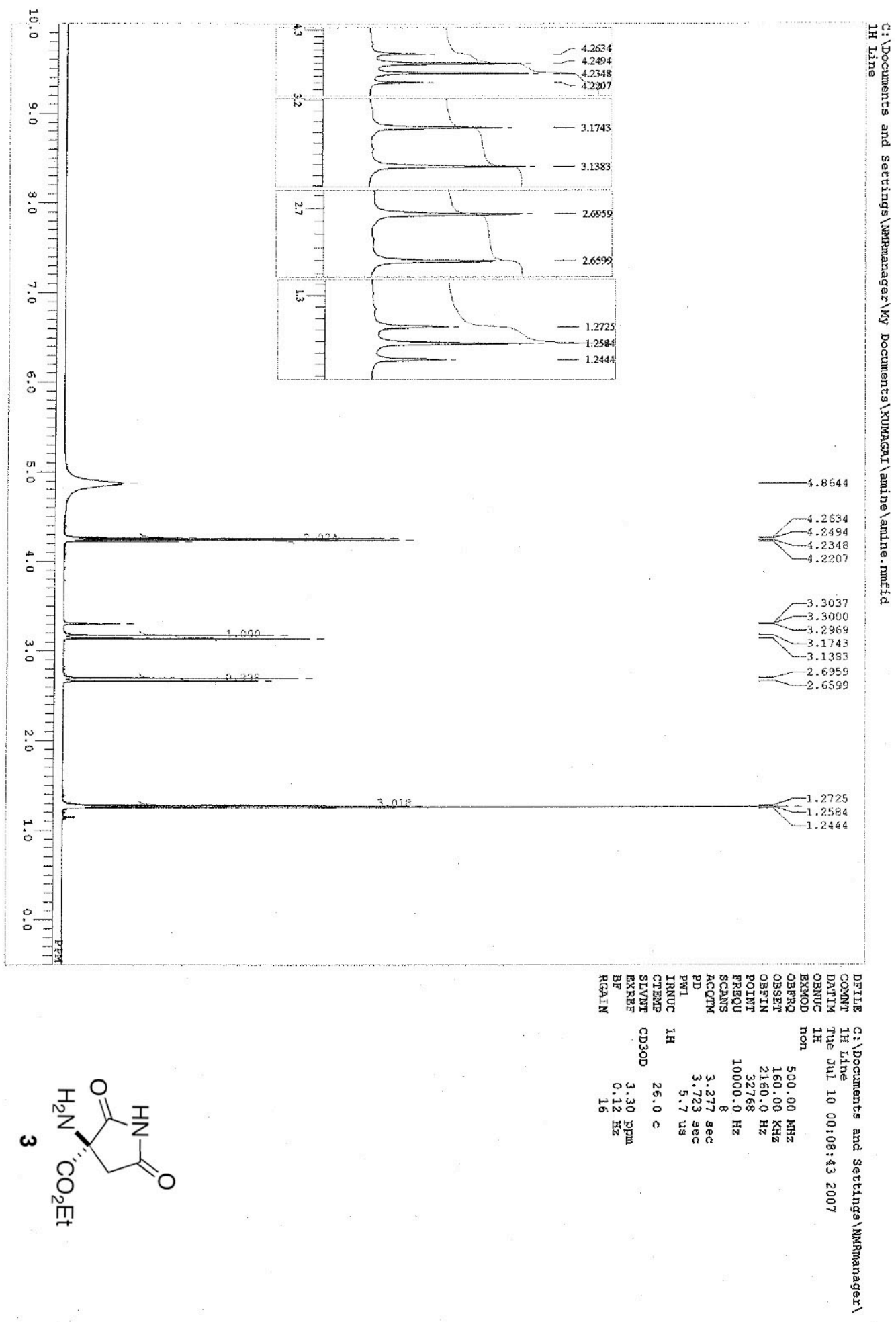




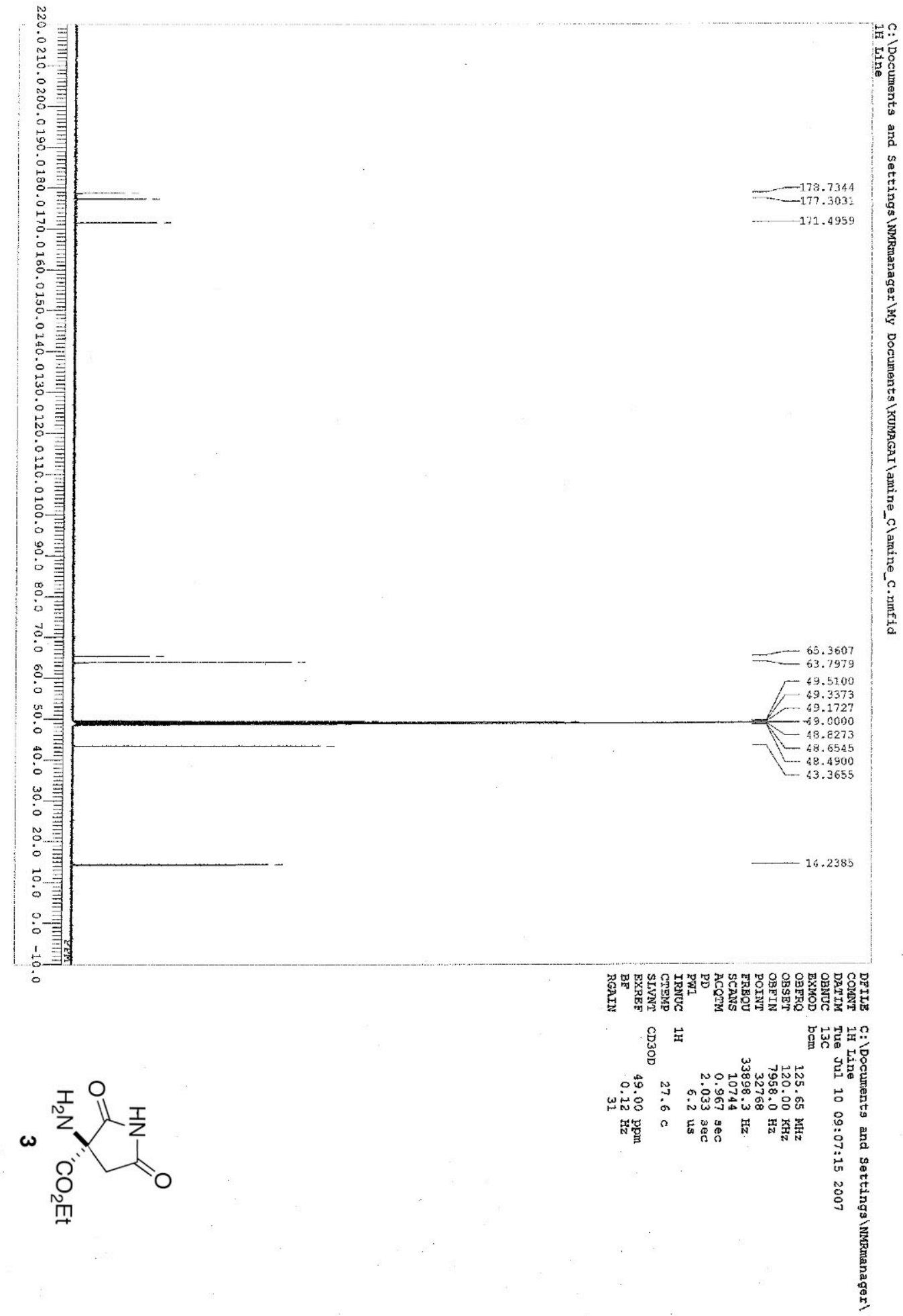




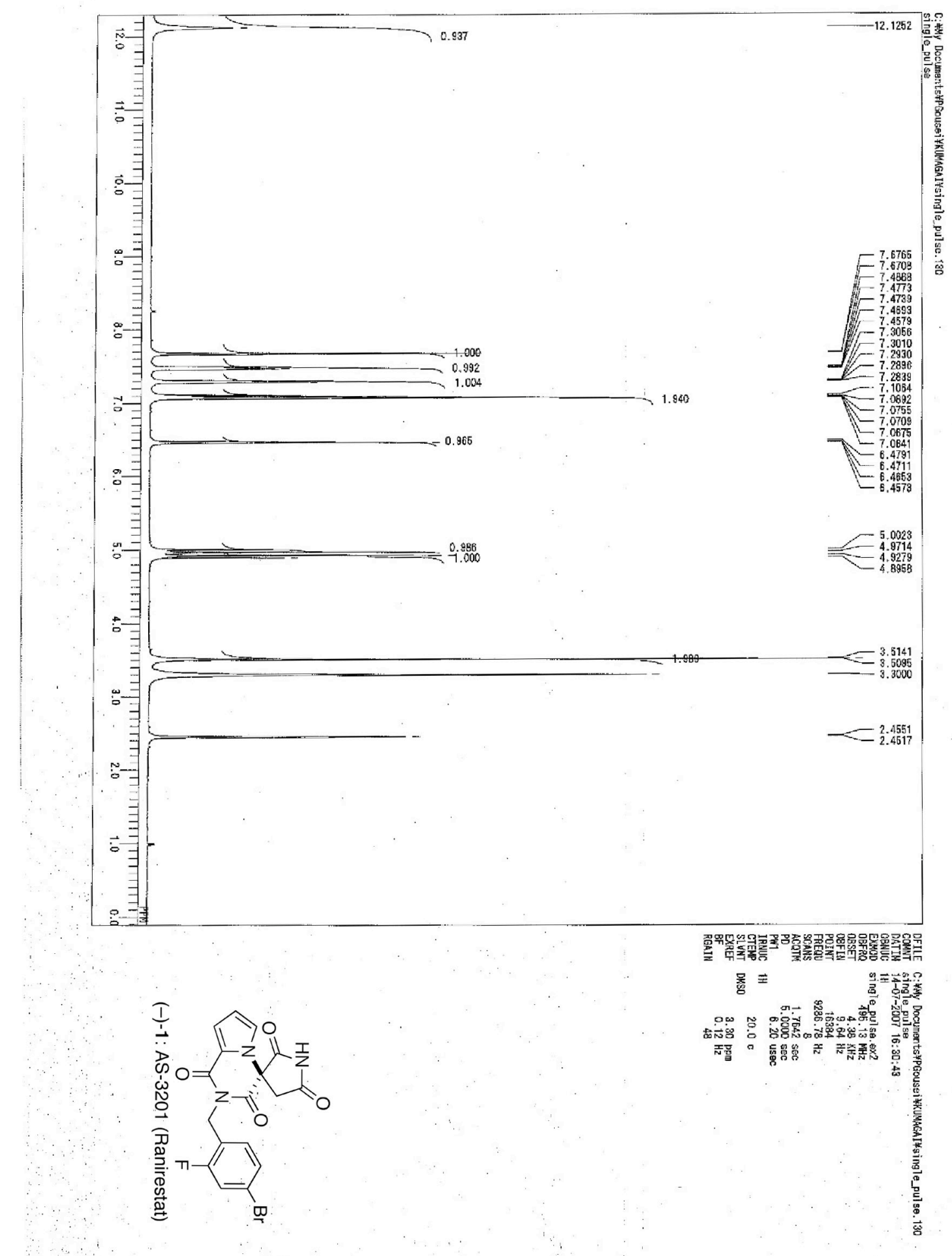




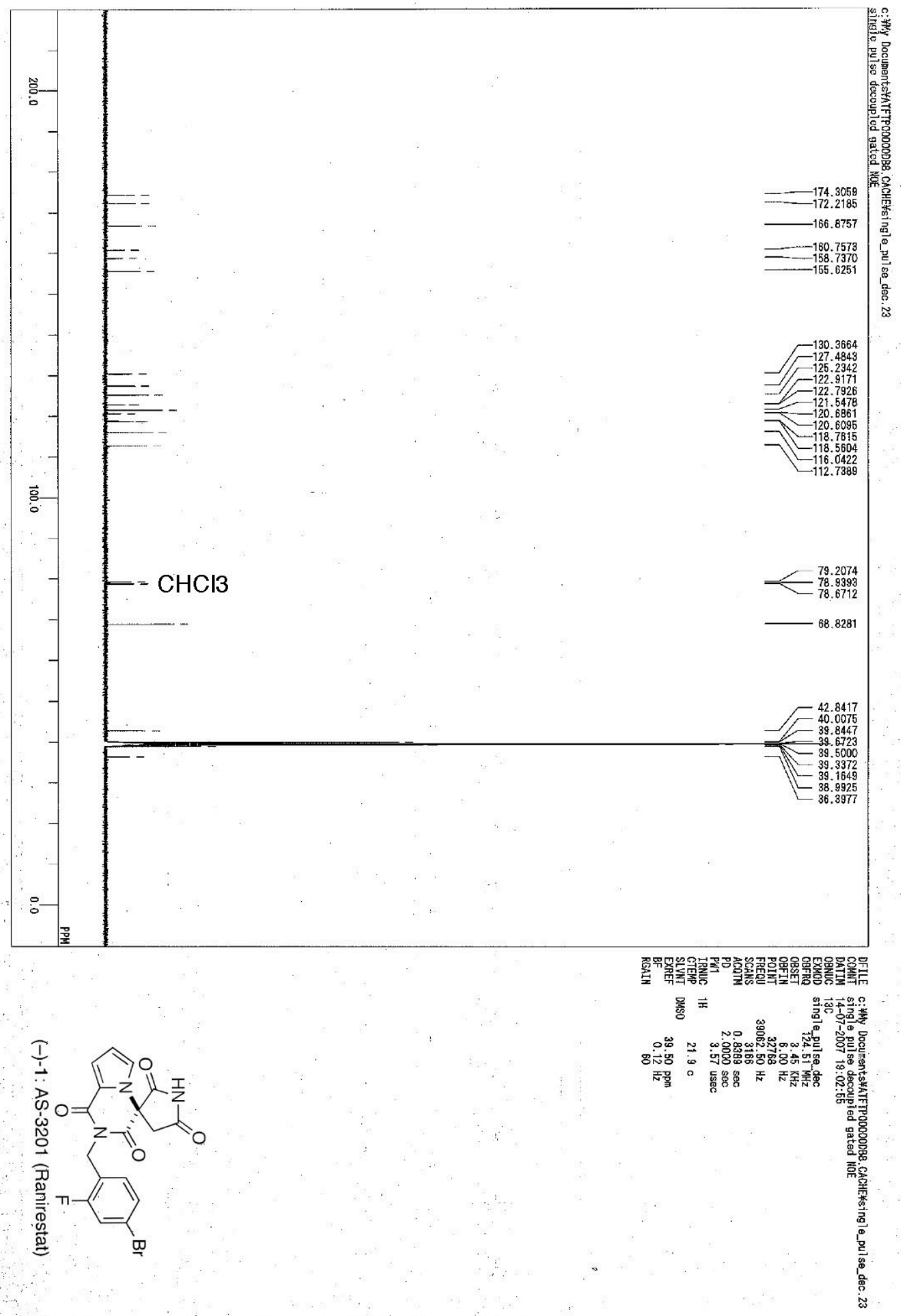

